\title{
Ірина Хемчян
}

завідувач відділу науково-методичного забезпечення діяльності мережі освітянських бібліотек ДНПБ України імені В. О. Сухомлинського, e-mail:metodist08@i.ua

ORCID id: 0000-0003-0885-8899

\section{НАУКОВО-МЕТОДИЧНЕ ЗАБЕЗПЕЧЕННЯ ДІЯЛЬНОСТІ МЕРЕЖІ ОСВІТЯНСЬКИХ БІБЛІОТЕК МІНІСТЕРСТВА ОСВІТИ І НАУКИ УКРАЇНИ ТА НАЦІОНАЛЬНОЇ АКАДЕМЇ̈ ПЕДАГОГІЧНИХ НАУК УКРАЇНИ: ДОСВІД РОБОТИ ДЕРЖАВНОЇ НАУКОВО-ПЕДАГОГІЧНОЇ БІБЛІОТЕКИ УКРАЇНИ ІМЕНІ В. О. СУХОМЛИНСЬКОГО}

У статті висвітлено діяльність Державної науково-педагогічної бібліотеки України імені В.О.Сухомлинського як головного координаційного науковометодичного центру мережі освітянських бібліотек Міністерства освіти і науки України та Національної академії педагогічних наук України протягом 2000 - 2019 рр. Основні напрями науково-методичної роботи: дослідження змін, що відбуваються як в окремих бібліотеках, так і в мережі освітянських бібліотек загалом, розробка концептуальних, організаційно-управлінських, нормативно-інструктивних і методичних документів, надання методичної та консультативної допомоги (у тому числі дистанційно) фахівцям різних видів освітянських бібліотек 3 основних напрямів бібліотечної роботи, експертно-діагностичні виїзди на місця 3 метою проведення управлінського консультування освітянських бібліотек, створення системи методичних видань, що охоплює всі напрями діяльності освітянських бібліотек, забезпечення функціонування мережі освітянських бібліотек як єдиної системи, впровадження в практику роботи освітянських книгозбірень бібліотечних інновацій, організація системи підвищення кваліфікації фахівців освітянських бібліотек із застосуванням різних форм та методів, надання доступу до інформаційного ресурсу 3 питань бібліотекознавства, бібліографознавства, книгознавства, документознавства та інформаційної діяльності $з$ метою задоволення фахових потреб бібліотечних працівників, освітян, студентів, наукове співробітництво 3 провідними бібліотеками інших систем і відомств, іншими установами й організаціями незалежно від форм власності (у тому числі $з$ іноземними) тощо. У подальшому науково-методична робота Державної науковопедагогічної бібліотеки України імені В. О. Сухомлинського буде спрямована на пошук, систематизацію та трансформацію передових знань у галузі бібліотечної справи, генерування нових ідей, які сприятимуть інноваційному розвитку освітянських бібліотек.

Ключові слова: мережа, бібліотека, науково-методична діяльність, видання, збірник, науково-практичний захід. 
Постановка проблеми. Державна науково-педагогічна бібліотека України імені В. О. Сухомлинського (ДНПБ України ім. В. О. Сухомлинського) відповідно до чинних законодавчих актів України, Стратегії розвитку ДНПБ на 2017-2026 рр. є головним координаційним, науково-методичним центром мережі освітянських бібліотек Міністерства освіти і науки України та Національної академії педагогічних наук України (МОН України та НАПН України).

Діяльність ДНПБ України ім. В. О. Сухомлинського з науково-методичного забезпечення мережі освітянських бібліотек має науково-прикладний характер і зосереджена на розв'язанні актуальних питань інформаційного забезпечення освіти. У бібліотеці цей напрям розробляє відділ науково-методичного забезпечення діяльності мережі освітянських бібліотек.

Метою науково-методичного забезпечення мережі освітянських бібліотек $\epsilon$ сприяння вдосконаленню їх діяльності, упровадження інноваційного досвіду в практику роботи, підвищення фахового рівня бібліотечних працівників. Протягом 2000-2019 рр. розроблялися різні аспекти науково-методичного забезпечення в процесі виконання шести науково-дослідних тем. Серед головних результатів наукових досліджень: висвітлення основних періодів становлення й розвитку освітянських бібліотек в Україні, започаткування систематичних моніторингових досліджень основних напрямів діяльності бібліотек, розроблення теоретико-методичних й організаційних засад формування єдиної мережі освітянських бібліотек України та системи їх науково-методичного забезпечення, розроблення форм i методів підвищення фахового рівня бібліотечних працівників.

Мета статті - розкриття здобутків науково-методичної діяльності, зокрема відділу науково-методичного забезпечення діяльності мережі освітянських бібліотек ДНПБ України ім. В. О. Сухомлинського.

Виклад основного матеріалу. 30 жовтня 2019 р. ДНПБ України ім. В. О. Сухомлинського відзначає свій двадцятирічний ювілей. Бібліотеку створено з ініціативи Академії педагогічних наук України (АПН України) та МОН України на базі фондів двох спеціальних педагогічних бібліотек - наукової 
бібліотеки Інституту педагогіки АПН України та Центральної педагогічної бібліотеки МОН України. Бібліотека має статус науково-дослідної установи і входить до складу НАПН України. У 2003 р. бібліотеці присвоєно ім’я видатного українського педагога В. О. Сухомлинського.

ДНПБ України ім. В. О. Сухомлинського одна 3 провідних галузевих бібліотек України, яка здійснює бібліотечно-інформаційне забезпечення національної системи освіти, сприяє проведенню наукових досліджень в галузі педагогіки, психології, методик викладання окремих навчальних предметів, а також надає допомогу в освіті й самоосвіті вченим, педагогам, бібліотекарям, учнівській молоді. Основними напрямами діяльності бібліотеки $є$ науководослідний, науково-бібліотечний і науково-методичний. У рамках науководослідної роботи бібліотекою реалізуються комплексні наукові проєкти з питань галузевого бібліотекознавства, бібліографознавства, книгознавства, науковоінформаційної діяльності, педагогічного джерелознавства та біографістики, що сприяє підвищенню наукового потенціалу бібліотеки, інтеграції іï ресурсів у світовий освітній інформаційний простір, впровадженню результатів науководослідної роботи в практику роботи бібліотек освітянської галузі. Відповідно до Постанови Кабінету Міністрів України «Про створення Державної науковопедагогічної бібліотеки» від 30 жовтня 1999 р. № 2018 і згідно з ії Статутом на бібліотеку покладено функції головного координаційного науково-методичного центру мережі освітянських бібліотек МОН України та НАПН України.

У 2003 р. ДНПБ України ім. В. О. Сухомлинського вперше в Україні створено й реалізовано на практиці концептуальну модель об'єднання різних видів педагогічних і навчально-педагогічних бібліотек як спеціальних у мережу, що закріплено Положенням про мережу бібліотек Міністерства освіти і науки України та Національної академії педагогічних наук України [4]. Сьогодні до складу мережі входять понад 15000 бібліотек: три провідні галузеві бібліотеки ДНПБ України ім. В. О. Сухомлинського, Львівська обласна науково-педагогічна бібліотека, науково-педагогічна бібліотека м. Миколаєва; бібліотеки закладів вищої освіти I-IV рівнів акредитації педагогічного та інженерно-педагогічного 
профілів; обласні інститути післядипломної педагогічної освіти; наукові інститути НАПН України; установи професійно-технічної, середньої та позашкільної освіти; районні (міські) методичні кабінети (центри). Для реалізації покладеної на ДНПБ України ім. В. О. Сухомлинського функції методичного центру визначено відповідні напрями в ії діяльності [5], зокрема, розроблення теоретико-методологічних основ функціонування бібліотеки і мережі бібліотек МОН України та НАПН України; формування інтегрованого галузевого інформаційного ресурсу; впровадження інноваційних форм і методів роботи в діяльність бібліотек мережі; підвищення кваліфікації бібліотечних працівників; формування та надання доступу до інформаційного ресурсу 3 питань бібліотекознавства, бібліографознавства i книгознавства в традиційній та електронній формах.

32000 р. у структурі бібліотеки функціонує відділ науково-методичного забезпечення діяльності мережі освітянських бібліотек (первинна назва науково-методичний відділ), який очолює І. І. Хемчян. Робота відділу охоплює кілька взаємопов'язаних напрямів - аналітичний, науково-методичний, інформаційний, інноваційний та підвищення кваліфікації бібліотечних фахівців. Науково-методичне забезпечення грунтується на аналітичній діяльності, що дає можливість виявляти короткострокові тенденції та відстежувати стратегічні зрушення в діяльності бібліотек мережі. Починаючи з 2001 р., відділом видавалися аналітичні огляди з питань діяльності різних видів бібліотек (один раз на три роки), в яких висвітлено інформацію щодо формування та використання інформаційних ресурсів, впровадження інформаційних технологій, довідково-бібліографічної діяльності, методичної роботи, кадрового забезпечення. У 2011 р., з огляду на необхідність модернізації діяльності бібліотек мережі, співробітниками відділу розроблено й реалізовано нову концепцію щорічного комплексного довідкового інформаційно-аналітичного видання «Провідні освітянські бібліотеки в просторі i часі: моніторинг діяльності» [6]. 
На основі результатів аналізу статистичної інформації у виданні подано рекомендації щодо науково-методичної програми використання підсумків аналізу в удосконаленні бібліотечної практики. У цьому ж році вперше в Україні за ініціативою ДНПБ України ім. В. О. Сухомлинського проведено паспортизацію шкільних бібліотек, яка не тільки сприяла приверненню уваги до їхніх проблем, а й стала підставою для підготовки наказу МОН України «Про модернізацію діяльності бібліотек загальноосвітніх навчальних закладів». Аналітична діяльність ДНПБ України ім. В. О. Сухомлинського - це не тільки накопичення цінної інформації про діяльність зазначених бібліотек, а й важливий важіль, що стимулює їх розвиток. Як показує практичний досвід, науковоаналітична діяльність має тісний зв'язок 3 іншими напрямами науковометодичної роботи, зокрема з розробленням й впровадженням у практику роботи бібліотек широкого спектра інструктивно-методичних документів. Бібліотека розробила і реалізувала в практиці роботи освітянських бібліотек понад 200 документів. Нині здійснюється оновлення положень для шкільних бібліотек. Усі документи, розроблені ДНПБ України ім. В. О. Сухомлинського в період 20002019 pp., систематизовано й включено в чотири випуски збірника «Організаційно-управлінські, нормативно-інструктивні і методичні документи для мережі освітянських бібліотек МОН України та НАПН України» [2].

Важливою формою методичного забезпечення $є$ також підготовка для бібліотек мережі методичних видань, різноманітних як за характером, так і за цільовим призначенням. Серед найбільш затребуваних такі посібники, як: «Анотування як процес аналітико-синтетичної переробки інформації», «Реферування як процес мікроаналітичного згортання інформації», «Індексування документів ключовими словами», «Предметизація документів 3 питань освіти, педагогіки, психології», «Методика бібліографування», «Формування інформаційного ресурсу 3 питань бібліотекознавства, бібліографознавства, книгознавства, документознавства в традиційній та електронній формах в освітянських бібліотеках», «Бібліографічне оформленні наукових робіт». 
Такі видання, як «Організація роботи бібліотеки загальноосвітнього навчального закладу», «Планування i звітність бібліотеки інституту післядипломної педагогічної освіти», «Перевірка бібліотечних фондів», «Формування інформаційної культури учнів загальноосвітніх навчальних закладів», бібліографічний огляд «Дитина і книга: погляд крізь призму часу», бібліографічний покажчик «Науково-інформаційна діяльність: теорія i практика», методичні рекомендації «Патріотичне виховання в шкільних бібліотеках: методи та підходи» підготовлено в серії «На допомогу професійної самоосвіти фахівців педагогічних бібліотек», яку видає ДНПБ України ім. В. О. Сухомлинського 32003 р. Першим виданням цієї серії був бібліографічний покажчик «Бібліотека навчального закладу в контексті інформатизації суспільства».

Через популярність покажчик виходить як продовжуване видання, у 2019 р. вийшов його четвертий випуск [1]. Протягом двох останніх років у цій серії вийшло два актуальних практичних посібники для шкільних бібліотекарів «Впровадження Універсальної десяткової класифікації в практику роботи бібліотек загальноосвітніх і професійно-технічних навчальних закладів» та «Сучасна шкільна бібліотека: організація роботи». Значна частина видань, підготовлених методичним центром, друкується в науково-методичному часописі «Шкільна бібліотека плюс», заснованому за підтримки МОН України в 2002 р. На сторінках професійного видання також систематично публікуються законодавчі та нормативно-правові документи, методичні рекомендації, висвітлюється український і зарубіжний досвід. Щорічно у вересневому номері друкується «Календар знаменних і пам'ятних дат в галузі освіти і педагогічної науки», головною метою якого $є$ надання практичної допомоги педагогічним i науково-педагогічним кадрам, студентам, бібліотекарям в отриманні компетентної інформації про ту чи іншу подію або особистість. Готуючи власні видання, методичний центр вживає заходів щодо активізації видавничої діяльності провідних бібліотек мережі. Починаючи 32006 р., щорічно аналізується і систематизується інформація про їх інформаційно-видавничу 
діяльність та основні заходи з підвищення кваліфікації. Результатом такої роботи $\epsilon$ «Довідник науково-інформаційної діяльності та основних заходів, спрямованих на підвищення професійної майстерності фахівців бібліотек системи освіти» [3]. 3 огляду на те, що у більшості бібліотек обмежене фінансування на відрядження для участі в науково-практичних заходах, особливо актуальною в довіднику є інформація про проведення інтернет-семінарів, вебінарів, які дають можливість у режимі реального часу брати участь в обговоренні доповідей, використовувати набутий досвід для впровадження в практику своєї діяльності.

Усвідомлюючи важливість поставлених перед бібліотеками освітянської мережі завдань, ДНПБ України ім. В. О. Сухомлинського як головний координаційний науково-методичний центр, приділяє велику увагу питанням розвитку та модернізації системи підвищення кваліфікації бібліотечних працівників. Нині у бібліотеках мережі працює близько 20000 фахівців, які до 2000 p. не мали повноцінної системи підвищення кваліфікації. I тільки зі створенням ДНПБ України ім. В. О.Сухомлинського така система почала формуватися й розвиватися. У 2002 p. бібліотека провела перший Всеукраїнський науково-практичний семінар «Тенденції розвитку бібліотек системи освіти: історія та сучасний стан». За підтримки МОН України, НАПН України, обласних і міських управлінь освіти і науки бібліотека щорічно проводить чимало різних заходів, що сприяють вивченню, поширенню й впровадженню кращого інноваційного досвіду роботи бібліотек мережі.

Особливою популярністю користуються Всеукраїнські вебінари, що відкривають широкі можливості для впровадження дистанційних форм підвищення кваліфікації.

ДНПБ України ім. В.О.Сухомлинського приділяє особливу увагу проведенню заходів для шкільних бібліотек, які є найчисленнішою складовою частиною мережі (14662 бібліотеки). Так, за ініціативи бібліотеки та за підтримки Української асоціації проведення бібліотечної секції в рамках Міжнародних та Всеукраїнських педагогічних читань «Василь Сухомлинський у діалозі з сучасністю». 
Участь шкільних бібліотекарів у педагогічних читаннях надихає їх на пошук нових підходів до виховання у молодого покоління любові до книги та інтересу до читання. Значною подією також для шкільних бібліотекарів стало щорічне проведення (з 2014 р.) у рамках Міжнародного місячника шкільних бібліотек Всеукраїнського місячника шкільних бібліотек. Місячник сприяє формуванню в соціумі зацікавленого ставлення до професії шкільного бібліотекаря, покликаного забезпечувати створення оптимальних умов для реалізації освітніх і виховних завдань Нової української школи шляхом виконання інформаційної, освітньої, культурної та дозвіллєвої функцій.

Щороку Всеукраїнський місячник відбувається під різними гаслами, що відображають актуальні напрями роботи шкільної бібліотеки («Шкільна бібліотека - стратегічний партнер освіти», «Виховуємо громадянина - патріота України», «Книга і читання - важливий фактор у вихованні духовних цінностей учнів», «Шкільна бібліотека за здоровий спосіб життя», «Шкільна бібліотека центр творчого розвитку дитини» (до 100-річчя від дня народження В. О. Сухомлинського) тощо. У 2019 р. Всеукраїнський місячник проходить під гаслом «Бібліотека Нової української школи - простір для освітніх можливостей кожного учня». Кожного року до Всеукраїнського місячника бібліотека готує рекомендації щодо його проведення. Підсумки Всеукраїнського місячника традиційно підбиваються на вебінарі, який проводять за підтримки ТОВ «Microsoft Україна». Кращі мультимедійні презентації, відеоролики, буктрейлери розміщено окремими тематичними блоками на вебпорталі ДНПБ України ім. В. О. Сухомлинського. 3 ініціативи бібліотеки 32012 р. організовується Всеукраїнський конкурс «Шкільна бібліотека». Основними завданнями цього конкурсу є оптимізація діяльності шкільних бібліотек - залучення дітей до читання, формування інформаційної, бібліотечно-бібліографічної та читацької культури учнів, виявлення інноваційного досвіду роботи, підвищення рівня професійної компетентності шкільних бібліотекарів, сприяння підвищенню престижу професії шкільного бібліотекаря, привернення уваги місцевих органів виконавчої влади, громадськості до проблем шкільних бібліотек. Всеукраїнський 
конкурс «Шкільна бібліотека 2019-2020» проходитиме в трьох номінаціях «Модель бібліотеки Нової української школи», «Медіакультура в бібліотечному просторі», «Бібліотека - територія читання».

У 2018 р. в рамках IX Львівського міжнародного бібліотечного форуму «Бібліотек@- творимо свободу» за ініціативи ДНПБ України ім. В. О. Сухомлинського спільно з Львівською обласною науково-педагогічною бібліотекою проведено панельну дискусію «Бібліотека Нової української школи: реалії та перспективи».

Постійно піклуючись про професійний розвиток бібліотекарів, ДНПБ України ім. В. О. Сухомлинського впроваджує нові форми підвищення кваліфікації. Починаючи з 2015 р., започатковано проведення бібліотекознавчого лекторію, лекторами якого $є$ наукові співробітники бібліотеки та провідні фахівці Української бібліотечної асоціації. Запропонована форма підвищення кваліфікації дає можливість фахівцям бібліотек міста Києва та Київської області прослухати на базі бібліотеки лекції з обраної тематики в зручний для них час. Для надання можливості прослухати лекції бібліотекарям 3 інших регіонів передбачається розміщення на порталі бібліотеки їх відеозаписів. Усвідомлюючи, що інноваційний розвиток бібліотечної справи України потребує від учених, бібліотекарів-практиків вивчення спадщини українських і зарубіжних бібліотекознавців, бібліографознавців, книгознавців та документознавців, науковці відділу працюють над створенням віртуального інформаційного ресурсу «Видатні бібліотекознавці, бібліографознавці, книгознавці і документознавці України i світу» [http://dnpb.gov.ua/ua/iнформаційнобібліографічні-ресурси/видатні-бібліотекознавці]. У згаданому ресурсі підготовлено інформацію про п'ятнадцятьох персоналій, серед яких: український бібліограф, книгознавець, бібліотекознавець, історик Л. У. Биковський; історик української бібліографії, бібліограф-практик М. П. Гуменюк; видатний бібліотекознавець i бібліограф, автор «Десяткової класифікації», один 3 найвидатніших бібліотечних діячів США, засновник школи бібліотечної справи при Колумбійському університеті Мелвілу Дьюї; бельгійський бібліограф, 
книгознавець, документаліст, громадський діяч, один із тих, кого вважають батьками-засновниками теорії інформатики Поль Отле; видатний український учений, культуролог, історик, педагог, бібліотекознавець, книгознавець, журналіст, музеєзнавець, бібліограф, біографіст С. А. Сірополко; видатний бібліотекознавець, бібліограф, організатор першого в Росії наукового відділу бібліотекознавства Л. Б. Хавкіна; відомий український учений-бібліотекознавець, документознавець, доктор історичних наук, професор, член Міжнародної академії інформатизації М. С. Слободяник; директор Науково-педагогічної бібліотеки міста Миколаєва Т. І. Роскіна та інші.

У 2015 р. інформаційний ресурс поповнено персоналією вченогобібліотекознавця, педагога, першого директора - організатора ДНПБ України ім. В. О. Сухомлинського, кандидата історичних наук, заслуженого працівника культури України П. І. Рогової. У 2009 р. саме за їі ініціативою створено цей проект, який сприяє самоосвіті бібліотекарів шляхом поглиблення їх знань у питаннях розвитку зарубіжного та вітчизняного бібліотекознавства. Також надає допомогу у підвищенні професійного рівня бібілотекарів серія біобібліографічних покажчиків «Майстри бібліотечної справи». Сьогодні серію представлено трьома виданнями, які присвячені професійним досягненням відомих українських бібліотекознавців, таких, зокрема, як кандидат історичних наук, заслужений працівник культури України П. І. Рогова, доктор історичних наук, професор, заслужений працівник культури України Т. І. Ківшар, кандидат педагогічних наук, доцент, одна із засновників Київського державного інституту культури (нині - Київський національний університет культури і мистецтв) Л. П. Одинока. 3 виданнями можна ознайомитися в кабінеті бібліотекознавства, який функціонує з 2000 р. у відділі науково-методичного забезпечення діяльності мережі освітянських бібліотек. Для віддалених користувачів, які не мають можливості отримувати методичну допомогу безпосередньо в бібліотеці, на іiі вебпорталі [http://nnpb.gov.ua/ua/] створено рубрику «Бібліотечному фахівцю». Наповнення рубрики актуальними матеріалами $є$ одним із головних завдань 
роботи відділу, адже від цього залежить сенс методичної роботи в інформаційному середовищі.

Із метою консолідації та професійного розвитку шкільних бібліотекарів України за ініціативи директора бібліотеки, доктора педагогічних наук, професора, члена-кореспондента НАПН України, заслуженого діяча науки і техніки України Л. Д. Березівської в структурі Української бібліотечної асоціації створено секцію працівників шкільних бібліотек, яку очолює завідувач відділу науково-методичного забезпечення діяльності мережі бібліотек системи освіти ДНПБ України ім. В. О. Сухомлинського I. I. Хемчян [https://ula.org.ua/sekciyikrugli-stoli/372-sekciya-pracivnikiv-specialnih-bibliotek]. Секція забезпечує своїм членам широкі можливості для професійного зростання, обміну досвідом роботи та ідеями, сприяє зміцненню інформаційної бази національної системи освіти, а також створенню сучасного бібліотечно-інформаційного середовища навчальних закладів.

У 2016 р. інформацію про здобутки науково-методичного забезпечення функціонування мережі освітянських бібліотек висвітлено у виданні НАПН України «Національна доповідь про стан і перспективи розвитку освіти в Україні» [8]. 14 листопада 2018 р. на черговому засіданні Президії Національної академії педагогічних наук України заслухано питання «Про науково-методичне забезпечення функціонування мережі освітянських бібліотек МOH України і НАПН України».

Президією зазначено, що науково-методична діяльність ДНПБ України iм. В. О. Сухомлинського щодо забезпечення функціонування мережі освітянських бібліотек МОН України та НАПН України відповідає пріоритетам державної освітньої політики, спрямована на розвиток мережі, створення належних умов для якісного інформаційного забезпечення фахових потреб науковців і практиків освітянської галузі, розкриття потенціалу ресурсів бібліотеки як складника науково-інформаційної структури освіти України.

Висновки. Огляд науково-методичної діяльності ДНПБ України ім. В. О. Сухомлинського, висвітлений у статті, свідчить про те, що вона 
$€$ результативною й вагомою, постійно розвивається і вдосконалюється відповідно до змін, що відбуваються як в освітній, так і в бібліотечній сферах. Діяльність бібліотеки спрямована на розвиток мережі, створення належних умов для якісного інформаційного забезпечення фахових потреб науковців і практиків галузі, розкриття потенціалу ресурсів бібліотек як складників науковоінформаційної структури освітянської галузі України.

Виклики сучасності поставили перед ДНПБ України ім. В. О. Сухомлинського важливе завдання - підготовку нової стратегії розвитку мережі освітянських бібліотек МОН України та НАПН України, яку буде розроблено відповідно до Стратегії розвитку бібліотечної справи в Україні до 2025 року «Якісні зміни бібліотек для забезпечення сталого розвитку України», розробленої Міністерством культури України спільно 3 Українською бібліотечною асоціацією у 2015 р.

Сьогодні бібліотекою зроблено перші кроки в цьому напрямі - розроблено власну стратегію розвитку на 2016-2020 рр. [7], один з основних векторів якої присвячений розвитку бібліотеки як головного наукового, науково-методичного та координаційного центру мережі бібліотек МОН України та НАПН України. Цей напрям розвиватиметься 3 урахуванням загальних тенденцій та інноваційного розвитку бібліотечної справи як в Україні, так і за кордоном.

\section{Список використаних джерел}

1. Бібліотека навчального закладу в контексті інформатизації суспільства : наук.-допом. бібліогр. покажч. для б-к закл. заг. серед., проф.-техн., вищ. освіти. Вип. 4 / НАПН України, ДНПБ України ім. В. О. Сухомлинського ; упоряд.: А. І. Рубан, I. I. Хемчян ; наук. консультант Т. В. Добко ; бібліогр. ред. А. І. Рубан. Київ : б. в., 2019. 500 с. URL: http://dnpb.gov.ua/wp-content/uploads/2019/08/Biblioteka-navchalnogo-zakladu_vyp.4.pdf (дата звернення: 21.11.2019).

2. Довідник інструктивних матеріалів для освітянських бібліотек МОН України та НАПН України (2017-2019 рр.) / НАПН України, ДНПБ України ім. В. О. Сухомлинського ; упоряд.: І. І. Хемчян, Л. М. Бондар. Київ : б. в., 2019. 95 c. URL: http://dnpb.gov.ua/wpcontent/uploads/2019/06/Reference_book_of_instructive_2019.pdf (дата звернення: 21.11.2019).

3. Довідник науково-інформаційної й видавничої діяльності та основних заходів, спрямованих на підвищення професійної майстерності бібліотечних працівників освітянської галузі / НАПН України, ДНПБ України ім. В. О. Сухомлинського ; уклад.: О. Л. Гончаренко, I. I. Хемчян ; наук. ред. і відп. за вип. I. I. Хемчян. Київ : б. в., 2019. 129 с. URL: http://dnpb.gov.ua/wp-content/uploads/2015/12/directory_2019.pdf (дата звернення: 21.11.2019). 
4. Положення про мережу освітянських бібліотек Міністерства освіти і науки України та Академії педагогічних наук України : затв. спіл. наказом МОН України та АПН України від 30.05.2003 р. № 334/31. Інформ. зб. М-ва освіти і науки Украӥни. 2003. № 21. С. 27-32.

5. Положення про організацію науково-методичного забезпечення діяльності мережі освітянських бібліотек Міністерства освіти і науки України та Академії педагогічних наук України Державною науково-педагогічною бібліотекою України імені В. О. Сухомлинського : затв. вчен. радою ДНПБ України ім. В. О. Сухомлинського, протокол № 12 від 26 груд. 2006 р. Організачійно-управлінські, нормативно-інструктивні і методичні документи для освітянських бібліотек Міністерства освіти і науки Украӥни та Національноі академії педагогічних наук України (2006-2010 pp.): збірник / ДНПБ України ім. В. О. Сухомлинського ; уклад. І. І. Хемчян ; наук. ред.: П. І. Рогова, І. Г. Лобановська. Київ, 2010. С. 11-16. URL: http://dnpb.gov.ua/wp-content/uploads/2016/02/manage_1_4.pdf (дата звернення: 21.11.2019).

6. Провідні освітянські бібліотеки в просторі і часі: моніторинг діяльності : довід. стат. / НАПН України, ДНПБ України ім. В. О. Сухомлинського ; уклад.: О. Л. Гончаренко, I. I. Хемчян ; наук. ред. Т. В. Добко. Київ : б. в., 2019. 141 c. URL: http://dnpb.gov.ua/wpcontent/uploads/2019/06/Stat_zbirnyk_2019.pdf (дата звернення: 21.11.2019).

7. Стратегія розвитку Державної науково-педагогічної бібліотеки України імені В. О. Сухомлинського на 2017-2026 роки / ДНПБ України ім. В. О. Сухомлинського ; за заг. ред. Л. Д. Березівської ; авт.: Березівська Л. Д., Зозуля С. М., Страйгородська Л. І. Київ, 2017. $29 \mathrm{c}$.

8. Library and information support of education / Khemchian I. I. and others. National Report on the State and Prospects of Education Development in Ukraine / National Academy of Educational Sciences of Ukraine ; ed. by V. Kremen. Kyiv, 2017. P. 71-72.

\section{References}

1. Ruban, A. I., \& Khemchian, I. I. (Comps.). (2019). Biblioteka navchalnoho zakladu v konteksti informatyzatsii suspilstva: naukovo-dopomizhnyi bibliohrafichnyi pokazhchyk dlia bibliotek zakladiv zahalnoi serednoi, profesiino-tekhnichnoi, vyshchoi osvity [Library of educational institution in the context of informatization of society: scientific-auxiliary bibliographic index for libraries of institutions of general secondary, vocational-technical, higher education] (Issue 4). Kyiv: DNPB Ukrainy im. V. O. Sukhomlynskoho. Retrieved from http://dnpb.gov.ua/wpcontent/uploads/2019/08/Biblioteka-navchalnogo-zakladu_vyp.4.pdf [in Ukrainian].

2. Khemchian, I. I., \& Bondar, L. M. (Comps.). (2019). Dovidnyk instruktyvnykh materialiv dlia osvitianskykh bibliotek MON Ukrainy ta NAPN Ukrainy (2017-2019 rr.) [Reference book of instructive materials for education libraries of the Ministry of Education and Science of Ukraine and the National Academy of Pedagogical Sciences of Ukraine (2017-2019)]. Kyiv: DNPB Ukrainy im. V. O. Sukhomlynskoho. Retrieved from http://dnpb.gov.ua/wpcontent/uploads/2019/06/Reference_book_of_instructive_2019.pdf [in Ukrainian].

3. Honcharenko, O. L., \& Khemchian, I. I. (Comps.). (2019). Dovidnyk naukovo-informatsiinoi y vydavnychoi diialnosti ta osnovnykh zakhodiv, spriamovanykh na pidvyshchennia profesiinoi maisternosti bibliotechnykh pratsivnykiv osvitianskoi haluzi [Handbook for scientific information and publishing activities and main events aimed at improving professional skills of librarians in the sphere of education]. Kyiv: DNPB Ukrainy im. V. O. Sukhomlynskoho. Retrieved from http://dnpb.gov.ua/wp-content/uploads/2015/12/directory_2019.pdf [in Ukrainian].

4. Polozhennia pro merezhu osvitianskykh bibliotek Ministerstva osvity i nauky Ukrainy ta Akademii pedahohichnykh nauk Ukrainy: zatverdzheno spilnym nakazom Ministerstva osvity i nauky Ukrainy ta Akademii pedahohichnykh nauk Ukrainy vid 30.05.2003 r. № 334/31 [Regulation on the network of educational libraries of the Ministry of Education and Science of Ukraine and the Academy of Educational Sciences of Ukraine: approved by a joint decree of the Ministry of Education and Science of Ukraine and the Academy of Educational Sciences of May 30, 2003 
No. 334/31]. (2003). Informatsiinyi zbirnyk Ministerstva osvity i nauky Ukrainy - Information collection of the Ministry of Education and Science of Ukraine, 21, 27-32 [in Ukrainian].

5. Khemchian, I. I. (Comp.). (2010). Polozhennia pro orhanizatsiiu naukovo-metodychnoho zabezpechennia diialnosti merezhi osvitianskykh bibliotek Ministerstva osvity i nauky Ukrainy ta Akademii pedahohichnykh nauk Ukrainy Derzhavnoiu naukovo-pedahohichnoiu bibliotekoiu Ukrainy imeni V. O. Sukhomlynskoho: zatverdzheno vchenoiu radoiu DNPB Ukrainy im. V. O. Sukhomlynskoho, protokol № 12 vid 26 hrudnia 2006 r. [Position about the organization of scientific and methodological provision of activities of the network of educational libraries of the Ministry of Education and Science of Ukraine and the Academy of Educational Sciences of Ukraine of the V. O. Sukhomlinsky State Scientific and Pedagogical Library of Ukraine: approved by the Scientific Council of V. O. Sukhomlinsky SSPL of Ukraine, Minutes No. 12 of December 26, 2006]. Orhanizatsiino-upravlinski, normatyvno-instruktyvni i metodychni dokumenty dlia osvitianskykh bibliotek Ministerstva osvity $i$ nauky Ukrainy ta Natsionalnoi akademii pedahohichnykh nauk Ukrainy (2006-2010 rr.): zbirnyk - Organizational, administrative, regulatory and methodological documents for educational libraries of the Ministry of Education and Science of Ukraine and the National Academy of Educational Sciences of Ukraine (2006-2010): collection (pp. 11-16). Kyiv: DNPB Ukrainy im. V. O. Sukhomlynskoho. Retrieved from: http://dnpb.gov.ua/wpcontent/uploads/2016/02/manage_1_4.pdf [in Ukrainian].

6. Honcharenko, O. L., \& Khemchian, I. I. (Comps.). (2019). Providni osvitianski biblioteky v prostori $i$ chasi: monitorynh diialnosti: dovidnyk statystychnyi [Leading education libraries in space and time: monitoring of their activity: statistical reference book]. Kyiv: DNPB Ukrainy im. V. O. Sukhomlynskoho. Retrieved from http:/dnpb.gov.ua/wpcontent/uploads/2019/06/Stat zbirnyk_2019.pdf [in Ukrainian].

7. Berezivska, L. D., Zozulia, S. M., \& Straihorodska, L. I. (2017). Stratehiia rozvytku Derzhavnoi naukovo-pedahohichnoi biblioteky Ukrainy imeni V. O. Sukhomlynskoho na 2017-2026 roky [Development strategy of $V$. O. Sukhomlynskyi State Scientific and Pedagogical Library of Ukraine for 2017-2026]. Kyiv: DNPB Ukrainy im. V. O. Sukhomlynskoho [in Ukrainian].

8. Khemchian I. I. \& others. (2017). Library and information support of education. In V. Kremen (Ed.), National Report on the State and Prospects of Education Development in Ukraine (pp. 71-72). Kyiv: Pedahohichna dumka [in Ukrainian].

\section{Iryna Khemchian,}

Head of the Department for Providing Scientific and Methodical Support to Education Libraries, V.O. Sukhomlynskyi SSPL of Ukraine

e-mail: metodist08@i.ua

ORCID id: 0000-0003-0885-8899

\section{PROVIDING SCIENTIFIC AND METHODICAL SUPPORT TO THE SYSTEM OF EDUCATION LIBRARIES UNDER THE MINISTRY OF EDUCATION AND SCIENCE OF UKRAINE AND THE NATIONAL ACADEMY OF EDUCATIONAL SCIENCES OF UKRAINE: EXPERIENCE OF V.O. SUKHOMLYNSKYI STATE SCIENTIFIC AND PEDAGOGICAL LIBRARY OF UKRAINE}

The paper covers the activity performed at V.O. Sukhomlynskyi State Scientific and Pedagogical Library of Ukraine, which functions as a coordination, scientific and methodological centre within the system of education libraries under the Ministry of Education and Science of Ukraine and the National Academy of Educational Sciences of Ukraine during the period from 2000 to 2019. Here are the main directions of scientific and methodical work performed at the library: methodical study of changes taken place in certain 
libraries as well as the system of education libraries in general; development of conceptual, organisational, administrative, regulatory and methodological documents; providing specialists of education libraries with methodological and advisory assistance (including remote help) on library work; expert-diagnostic visits to education libraries for the purpose of library management consulting; creation of the system of methodical publications covering all areas of activity performed by education libraries; maintaining the functioning of the system of education libraries as a single system; introduction of library innovations into the work of education libraries; improvement of professional skills of the specialists of education libraries using different forms and methods; providing access to information resource on librarianship, bibliography studies, bibliology, documentation studies, and information activity in order to meet the professional needs of librarians, educators, and students; scientific cooperation with leading libraries of other systems, departments, institutions, and organisations, regardless form of ownership (including foreign establishments), etc. In the future, the scientific and methodical work of V. O. Sukhomlynskyi State Scientific and Pedagogical Library of Ukraine will be focused on searching for, systematising and transforming progressive knowledge in the field of library science, as well as on generating new ideas that will further the innovative development of education libraries.

Keywords: system, library, scientific and methodical activity, publications, collected papers, scientific and practical event. 